\title{
Origins of Aminergic Regulation of Behavior in Complex Insect Social Systems
}

\author{
J. Frances Kamhi ${ }^{1 *}$, Sara Arganda ${ }^{2,3}$, Corrie S. Moreau ${ }^{4}$ and James F. A. Traniello ${ }^{2,5}$ \\ ${ }^{1}$ Department of Biological Sciences, Macquarie University, Sydney, NSW, Australia, ${ }^{2}$ Department of Biology, Boston \\ University, Boston, MA, United States, ${ }^{3}$ Centre de Recherches sur la Cognition Animale, Centre de Biologie Intégrative, \\ Université de Toulouse, CNRS, UPS, Toulouse, France, ${ }^{4}$ Department of Science and Education, Field Museum of Natural \\ History, Chicago, IL, United States, ${ }^{5}$ Graduate Program for Neuroscience, Boston University, Boston, MA, United States
}

Neuromodulators are conserved across insect taxa, but how biogenic amines and their receptors in ancestral solitary forms have been co-opted to control behaviors in derived socially complex species is largely unknown. Here we explore patterns associated with the functions of octopamine (OA), serotonin (5-HT) and dopamine (DA) in solitary ancestral insects and their derived functions in eusocial ants, bees, wasps and termites. Synthesizing current findings that reveal potential ancestral roles of monoamines in insects, we identify physiological processes and conserved behaviors under aminergic control, consider how biogenic amines may have evolved to modulate complex social behavior, and present focal research areas that warrant further study.

Keywords: neuromodulation, biogenic amines, eusocial, social brain evolution, collective intelligence

\section{OPEN ACCESS}

Edited by:

Gabriella Hannah Wolff, University of Washington, United States

Reviewed by: Marco Atzori,

Universidad Autónoma de San Luis Potosí, Mexico Vicki Moore, Arizona State University, United States

*Correspondence: J. Frances Kamhi franne.kamhi@mq.edu.au

Received: 25 February 2017 Accepted: 22 September 2017 Published: 10 October 2017

Citation: Kamhi JF, Arganda S, Moreau CS and Traniello JFA (2017) Origins of Aminergic Regulation of Behavior in

Complex Insect Social Systems.

Front. Syst. Neurosci. 11:74. doi: 10.3389/fnsys.2017.00074

\section{INTRODUCTION}

The ubiquitous biogenic amines octopamine (OA), serotonin (5-HT) and dopamine (DA) activate neural circuitry to regulate behavior (Libersat and Pflueger, 2004; Bergan, 2015). The phylogenetic distribution of these neuromodulators suggests a deep evolutionary history predating the origin of the nervous system (Gallo et al., 2016). With few structural modifications, monoamines are functionally diverse in insects (Roeder, 1999; Mustard et al., 2005; Blenau and Thamm, 2011). Conserved aminergic circuits (Kravitz and Huber, 2003; Barron et al., 2010; Perry et al., 2016) and patterns of receptor expression (Roeder, 1999; Blenau and Thamm, 2011) control behavior in diverse species across insect orders. However, how monoamine neurotransmitter systems served as preadaptations for the evolution of derived behaviors associated with the transition from solitary life to sociality in insects is poorly understood. Insect colonies show remarkable variation in structure and degree of integration of worker actions that could underscore complex social behavior. Using well-resolved insect molecular phylogenies (Wiegmann et al., 2011; Song et al., 2012, 2015; Moreau and Bell, 2013; Regier et al., 2013; Schmidt, 2013; Misof et al., 2014; Wang et al., 2014), we explore the evolution of neuromodulation of social behavior (Supplementary Table S1) by analyzing patterns of monoamine function in solitary and social taxa (Figure 1; Supplementary Table S2).

\section{SOCIAL DECISION-MAKING SYSTEMS AND BEHAVIORAL DIVERSITY IN INSECTS}

Two neural circuits regulate vertebrate decision-making: the social behavior network, controlled by neuropeptides and gonadal steroids, and the mesolimbic reward system, activated primarily by DA (O'Connell and Hofmann, 2011a,b). These circuits act in concert to regulate social interactions and evaluate stimulus valence, respectively, forming the social decision-making 
network (O'Connell and Hofmann, 2011b, 2012). Insect social decision-making systems are poorly understood in comparison, although behavioral influences of neuromodulators are well known (Supplementary Table S2).

Neurochemical and neuroendocrine analyses of complex social behavior in insects have largely been limited to the species-rich Hymenoptera ( $>150,000$ species), which includes ants, bees and wasps with solitary, presocial and eusocial life histories. Solitary species are composed of individuals that live and forage alone and interact with conspecifics primarily during mating or territorial disputes. Presocial describes life histories that are intermediate between solitary and eusocial (Eickwort, 1981). Eusociality is defined by: (1) reproductive division of labor (the differentiation of fertile [queens and males] and sterile [workers] castes); (2) allomaternal care (cooperative care of immatures by workers); and (3) overlapping generations of reproductive and worker castes (queen longevity allowing coexistence with offspring). Varying degrees of sociality are found in a number of clades. Phase transitions from solitary to gregarious behavior occur in desert locusts (Order Orthoptera; Anstey et al., 2009; Ott and Rogers, 2010), beetles (Order Coleoptera) show multiple occurrences of the evolution of familial sociality, including biparental care (Costa, 2006; Cunningham et al., 2015; Panaitof et al., 2016), and one species of weevil is eusocial (Kent and Simpson, 1992). Solitary life histories predated eusociality in both the Hymenoptera (Wilson, 1971) and Isoptera, which diverged from cockroaches into entirely eusocial forms (Bourguignon et al., 2015). The evolution of a reproductive caste occurred once in ants and multiply in bees and wasps; diversification of workers, particularly in ants, has many independent origins (Oster and Wilson, 1978; Trible and Kronauer, 2017). Eusociality independently evolved in the Order Isoptera (termites, $>3000$ species; Thorne and Traniello, 2003).

Parental behavior, reproductive competition and foraging and defense strategies in solitary (Field et al., 2006, 2015; Thompson et al., 2014) and eusocial (Tibbetts, 2013) hymenopteran species reflect social decision-making, although neurochemical and neuroanatomical correlates of such systems are poorly understood (Ilies et al., 2015). For example, neural mechanisms underscoring vertebrate-like cognitive abilities, such as individual facial feature recognition in some eusocial wasps, are not known (Gronenberg et al., 2008; Sheehan and Tibbetts, 2011). Decision-making at the colony level is seen in collective (swarm) intelligence (Seeley, 2010; Jeanson et al., 2012; Sasaki and Pratt, 2012; Reid et al., 2015) and in part concerns worker interactions (Greene and Gordon, 2003; Greene et al., 2013) that may be causally related to brain neurotransmitter levels (Muscedere et al., 2012; Kamhi and Traniello, 2013; Kamhi et al., 2015; Hoover et al., 2016). Studies have focused on the aminergic control of worker interactions that contribute to social organization, including responsiveness to social signals and cues that regulate alloparental care, food exchange, nest construction, defensive behavior and foraging (reviewed in Kamhi and Traniello, 2013; Simpson and Stevenson, 2015; Hamilton et al., 2017). Studies have begun to explore genetic and epigenetic underpinnings of task performance and plasticity through state changes in behavior (Lucas and Sokolowski, 2009; Simola et al., 2016) that may involve neuromodulators.

\section{BEHAVIOR AND BIOGENIC AMINE FUNCTIONS IN INSECTS}

Genes controlling behavior in solitary insects regulate social behavior in eusocial species (LeBoeuf et al., 2013) and affect sensory receptor evolution (Baldwin et al., 2014). Monoamine functions in solitary insects likely reflect this conservation, and appear to have been preadaptive for eusocialty. To understand the evolution of neuromodulatory systems in insects, we organized available data on aminergic control into eight behavioral categories: activity, aggression, development, higherorder sensory integration, nutrition, reproduction, sensorimotor functions and social functions (defined in Supplementary Table S1). Behaviors may span multiple categories, such as parental care and mate selection involving reproduction and derived social functions. Statistical tests showed similar patterns of monoamine function in solitary and eusocial species (Supplementary Figure S1), although small sample sizes constrain inferences. While data on biogenic amine regulation is variable and fragmentary, some patterns emerge suggesting that aminergic circuitry has shifted in function during the transition from solitary to social life. Monoamines have been co-opted for social functions through receptor and circuitry evolution and have gained novel functions to regulate social behaviors. For example, 5-HT (Alekseyenko et al., 2010, 2014; Bubak et al., 2014) and OA (Stevenson et al., 2000; Hoyer et al., 2008; Zhou et al., 2008; Stevenson and Rillich, 2017) increase aggression in solitary insects. In social insects, aggression is associated with the ability to pheromonally distinguish nestmates from non-nestmates (Stroeymeyt et al., 2010; Sturgis and Gordon, 2012), and OA is implicated in improved nestmate recognition (Robinson et al., 1999; Vander Meer et al., 2008; Kamhi et al., 2015). OA may thus enhance sensitivity to pheromonal cues and regulate social interactions similarly in both solitary and social insects.

DA, 5-HT and OA are involved in regulating metamorphosis in solitary insects (Nässel and Laxmyr, 1983; Hirashima et al., 1999). In social insects, monoamines are associated with age-related behavioral changes and collateral physiological and neural development (Schulz et al., 2002; Seid and Traniello, 2005; Cuvillier-Hot and Lenoir, 2006; Wnuk et al., 2010; Giraldo et al., 2016). OA increases with age and is causally related to the transition from nursing to foraging in honey bees (Schulz et al., 2002). In ants, 5-HT, DA (Seid and Traniello, 2005; Cuvillier-Hot and Lenoir, 2006), and OA (Wnuk et al., 2010) increase with age; 5-HT, similar to OA in bees, is correlated with age-related initiation of foraging (Seid and Traniello, 2005) and sensitivity to pheromonal signals underscoring trail communication (Muscedere et al., 2012).

In respect to other behaviors, suppressing DA neurons in Drosophila melanogaster consistently inhibits aversive but not appetitive learning, whereas manipulating OA action produces the opposite pattern (Schwaerzel et al., 2003; 


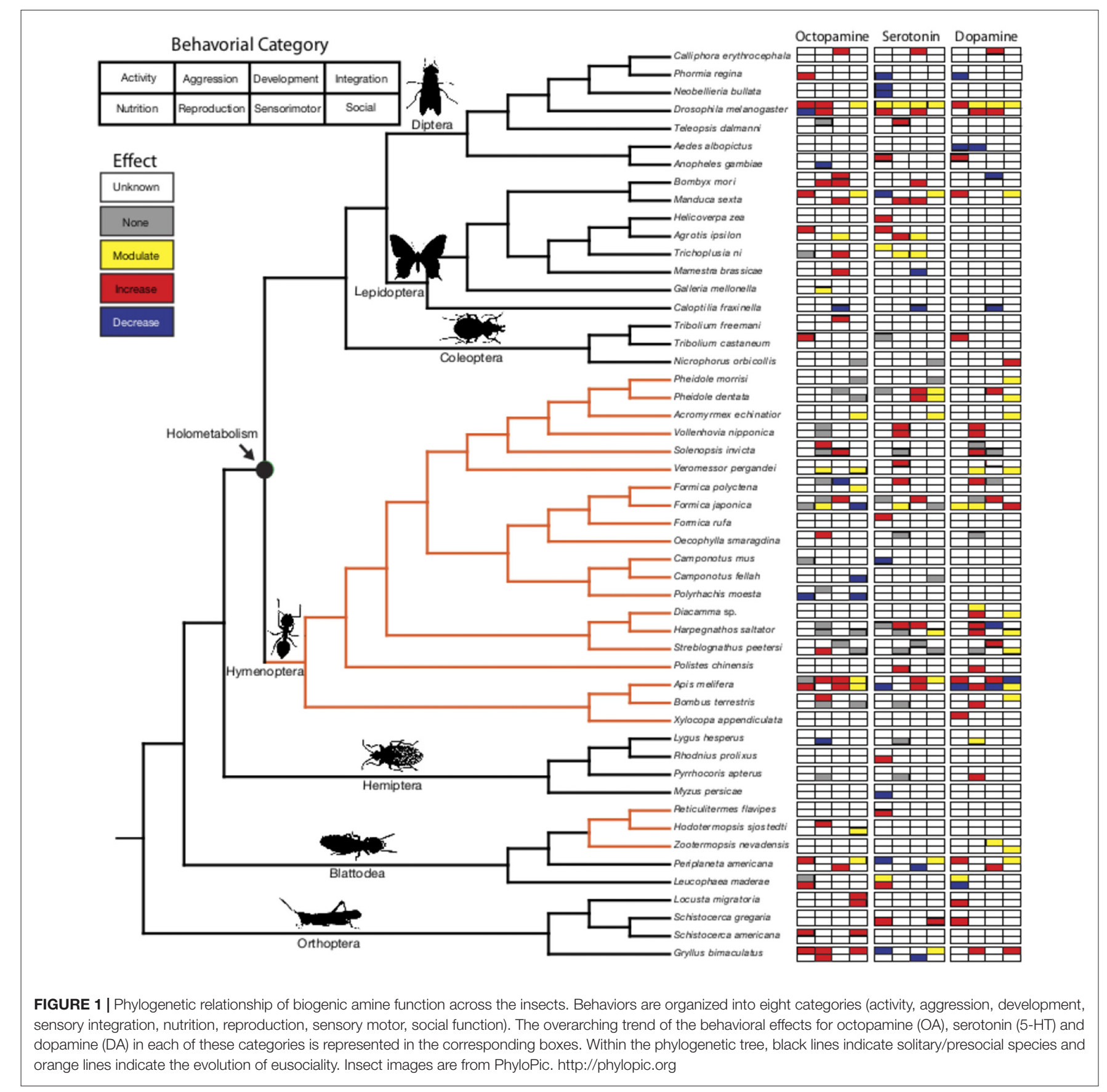

Claridge-Chang et al., 2009; Aso et al., 2010). Similar patterns have been found in honey bees (Mercer and Menzel, 1982; Hammer and Menzel, 1998). However, appetitive learning in social insects must be considered in respect to the social context, where foraging is dependent on the nutritional state of the colony rather than the individual (Traniello, 1977; Seeley, 1989). OA increases the likelihood of successful foragers waggle dancing, which communicates information about food location and quality to nestmates; this demonstrates that an amine may be adapted to serve a colony-level function in food collection rather than benefit individual nutrition (Barron et al., 2007).
Biogenic amines appear to have gained new functions associated with the regulation of social organization. DA correlates with increased receptivity and mating in solitary insects (Pastor et al., 1991; Neckameyer, 1998; Chvalova et al., 2014; Brent et al., 2016), and reproductive state in many hymenopterans (e.g., Sasaki et al., 2007). Honey bee and some ant workers are reproductively capable; however, both ant and honey bee queens release a pheromone, queen mandibular pheromone (QMP), that inhibits worker reproduction (Fletcher and Blum, 1981; Hoover et al., 2003) by acting through DA circuitry (Harris and Woodring, 1995; Boulay et al., 2001; Beggs et al., 2007). 
Aggressive interactions between workers to control reproductive dominance also affect DA levels (Shimoji et al., 2017). These studies suggest that in both solitary and eusocial insects DA regulates reproductive state, and DA additionally may be integral to the maintenance of reproductive division of labor and the resolution of reproductive competition in eusocial species.

\section{FOCAL QUESTIONS}

We identify four research areas, among several others, that are significant in the study of the neuromodulation of complex eusocial behavior.

\section{Altruism, Genes and Neuromodulators}

Altruism is evident in the sterility of workers and their fatal self-sacrificing behavior. Developmental programming controls ovarian function, feeding the queen and alloparental care, and likely regulates defensive responses that decrease the survival of altruistic workers. Correlations among DA, OA, their receptors, ovarian development and honey bee worker responsiveness to social signals of fertility have been identified (reviewed in Simpson and Stevenson, 2015; Hamilton et al., 2017). As discussed above, worker fertility is controlled by QMP, which also causes workers to feed and groom the queen and activates brain genes associated with alloparenting (Grozinger et al., 2003). Workers showing higher ovarian activity are less likely to show queen-directed behaviors (Galbraith et al., 2015). Honey bee ovarian development is associated with the expression of a tyramine receptor gene (Thompson et al., 2007) and brain levels of the OA receptor Oal (Cardoen et al., 2011; Galbraith et al., 2015; Sobotka et al., 2016). QMP also modulates DA receptor gene expression, decreases brain DA levels, and reduces activity possibly by inhibiting DA function in young workers (Beggs et al., 2007). Homologous systems appear to control reproduction in ants: QMP inhibits reproduction and DA may increase fertility (Boulay et al., 2001; Penick et al., 2014; Okada et al., 2015).

Together, these studies suggest that in eusocial insects DA regulates reproductive state and related social behaviors, which are key to altruism. Thompson et al. (2013) noted that "genes underlying altruism should coevolve with, or depend on, genes for kin recognition"; such genes specify recipients of altruistic actions. The regulation of polygyny (multiple queens) in ants and the direction of lethal aggression toward queens of a certain genotype, is under the control of the Gp-9 gene, which codes for an odorant-binding protein (Gotzek and Ross, 2007). This indicates that chemical communication underscores strategies associated with inclusive fitness. Nestmate recognition may be causally related to monoamine levels (Kamhi and Traniello, 2013; Kamhi et al., 2015; Hoover et al., 2016) and altruistic defense. Self-sacrifice is associated with defensive specializations of "soldiers," and may concern serotonergic circuits (Giraldo et al., 2013). Soldiers are more tolerant of risk; elevated monoamine levels or subcaste-specific receptor profiles may underscore their self-sacrificing behavior.

\section{Orchestration of Individual and Colony-Level Behavior}

Social decision-making networks in vertebrates and eusocial insects function in different contexts and favor, respectively, individual reproduction and inclusive fitness. Concepts such as social brain theory (Dunbar, 1998), developed for vertebrates, may vary in its applicability to eusocial insects (Lihoreau et al., 2012). Similarly, neuromodulators play a key role in the "orchestration of behavior" (Sombati and Hoyle, 1984; Hoyle, 1985), but analyses of organizational mechanisms should distinguish between the regulation of individual behavior by monoamines and the control of emergent colony properties by pheromones to determine whether the orchestration hypothesis can explain the control of these two systems (Kamhi and Traniello, 2013). The circuitry of social networks underscoring division of labor and collective action may concern interactions of communicating workers, which have been considered to be functionally similar to neurons (Couzin, 2009; Feinerman and Korman, 2017). Similarly, pheromones are behavioral releasers that may parallel neurotransmitter functions in circuits. The role of the "colony brain" in emergent group behavior is therefore in part constructed from the neurochemistry of individual worker brains that modulate responsiveness to social cues and signals as well as social interactions and pheromonal communication systems that modulate group decision-making. Kamhi and Traniello (2013) hypothesized that worker interactions may cause neuromodulatory and behavioral synchronization in collective action, and that monoamine titers could regulate cyclical activity. Control processes analogous to neural synchronization in vertebrate brains may underscore colony-level behavior.

An emergent action that holds promise for such an analysis is cooperative foraging, a goal-oriented system in which chemical signals control colony behavior (Czaczkes et al., 2015). Foraging effort is modified by the responses of individual workers to pheromones that induce and terminate foraging activity by affecting individual and group decisions. The ability of workers to render decisions that modify colony-level responses may be related to worker physical caste or age. OA underscores subcastespecific behavior in ants (Kamhi et al., 2015), and 5-HT in ants (Seid and Traniello, 2005; Seid et al., 2008) and OA in honey bees (Schulz et al., 2002) modulate age-related task transitions that involve striking shifts in stimulus environments within and outside of the nest. Biogenic amines may thus influence division of labor and collective action through changes in olfactory responsiveness.

\section{Nutrition and Biogenic Amines}

Nutrition has diverse effects on social behavior, from group aggregation to brain physiology (Simpson and Raubenheimer, 2012; Lihoreau et al., 2015). Diet influences levels of brain monoamines, which are derived from amino acids such as tryptophan and tyrosine (Crockett et al., 2009; Wada-Katsumata et al., 2011; Fernstrom, 2013). In insects, 5-HT, DA and OA modulate feeding behavior (Braun and Bicker, 1992; Falibene et al., 2012) through regulatory mechanisms that may be conserved between solitary and social species (Dacks et al., 2003; 
Haselton et al., 2009; Neckameyer, 2010). Serotonergic fibers innervate the insect digestive system in species-specific patterns of distribution (e.g., Klemm et al., 1986; Molaei and Lange, 2003; Falibene et al., 2012; French et al., 2014). In eusocial insects, food is exchanged among colony members through trophallaxis. In the foregut, the proventriculus controls the transfer of food to the midgut (for individual worker metabolism) and its retention in the crop (to be shared with colony members). In solitary insects, 5-HT increases crop contractions (Liscia et al., 2012), enabling regurgitation (Stoffolano et al., 2008). In honey bees (French et al., 2014) and some ants (Falibene et al., 2012), serotonergic fibers innervate both organs; in honey bees, 5-HT antagonists affect crop and proventriculus contractions (French et al., 2014). In eusocial insects, 5-HT may thus have been co-opted for food sharing, reducing individual feeding behavior and enabling trophallaxis when the crop is full.

In ants, nutrient requirements differ among colony members: workers mainly feed on carbohydrates for energy, whereas larvae require protein for development. Colonies with larvae collect food with higher protein content (Abril et al., 2007; Dussutour and Simpson, 2008, 2009); communication of nutritional needs (Farina and Grüter, 2009; LeBoeuf et al., 2016) may thus modify food choices of foragers. Adjusting protein and carbohydrate intake in ants may affect nestmate recognition (Liang and Silverman, 2000; Buczkowski et al., 2005), social immunity (Kay et al., 2014), and colony behavior (Kay et al., 2010, 2012). However, we do not know how nutritional interactions affect forager monoamine levels and behavior. 5-HT underlies a dietary switch toward foods with higher protein content in fruit flies (Vargas et al., 2010), and OA and DA levels influence individual and social control of feeding in some ants (Wada-Katsumata et al., 2011). Nutritional ecology varies across social insect clades and may significantly impact monoamine levels and trophic behavior.

\section{Ligand and Receptor Coevolution}

Biogenic amine receptor distribution in insect brains has been characterized primarily in fruit flies and honey bees (Blenau et al., 1998; Monastirioti, 1999; Blenau and Thamm, 2011; Sinakevitch et al., 2011). Receptor duplication has occurred throughout evolution and the same small number of monoamines appear to have been co-opted for use as ligands for duplicated receptors (Hauser et al., 2006). There are typically several types of receptors for each monoamine, which may lead to different regulatory mechanisms. For example, knocking out the 5-HT receptor d5-HT1A influences sleep in fruit flies (Yuan et al., 2006), whereas overexpression of receptor $\mathrm{d} 5$-HT1B reduces the ability to phase-shift in response to light cues (Yuan et al., 2005).

Receptor duplication and adaptation appears to have evolved before the divergence of fruit flies and honey bees, suggesting that solitary and social insects share common monoamine receptors (Hauser et al., 2006; Bauknecht and Jékely, 2017). If ligands, receptors, and downstream regulatory mechanisms are highly conserved across species, how have biogenic amine circuits evolved to control derived social behaviors? Monoamines may have species-specific effects on neural circuits, giving rise to different downstream regulatory effects and thus variable roles in modulating behavior. Activation of the DA receptor DopR1 increased stress-induced hyperactivity and modulated circadiandependent activity through different neural circuits in fruit flies (Lebestky et al., 2009). Social insects may have evolved distinct neural circuits to regulate social behaviors using the same signaling molecules as solitary species. Exploring biogenic amine receptors and downstream regulatory pathways involved in insect behavior and derived social functions will advance our understanding of how the eusocial insect brain evolved perceptual and cognitive capacities in association with sociality.

\section{CONCLUSION}

Broader sampling is required to gain phylogenetic insight into the evolution of aminergic control systems. Determining patterns of conservation and/or diversification of aminergic regulatory mechanisms of social behavior will benefit from studies of insect genera that include solitary and eusocial species. Despite the widespread activity of biogenic amines, functional patterns appear. 5-HT may control energy expenditure through feeding behavior and circadian rhythms, DA regulates fertility, thus modulating task performance in eusocial species, and OA modulates appetitive learning associated with feeding and nestmate recognition. Advances in epigenetics (Libbrecht et al., 2016), neurogenetics (Friedman and Gordon, 2016), and the integration of sociobiology and neurochemistry (Kamhi and Traniello, 2013) will aid in future research.

\section{AUTHOR CONTRIBUTIONS}

JFK, SA and JFAT compiled literature. SA performed statistical analyses and created associated figures, and CSM created the phylogenetic presentation of aminergic control of behavior. JFK, SA and JFAT prepared drafts of the manuscript. All authors contributed to the conception of the perspective, analysis and synthesis of material, manuscript revision and gave final approval for publication.

\section{ACKNOWLEDGMENTS}

Andrew Hoadley and Dr. Alfonso Pérez-Escudero commented on the manuscript, and Dr. Iulian Ilies gave helpful statistical advice. This work was supported by a Marie Skłodowska-Curie Individual Fellowship (funding from the European Union's Horizon 2020 research and innovation programme under grant agreement No. BrainiAnts-Project 660976) to SA, NSF grant IOS 1354193 to CSM, and NSF grant IOS 1354291 to JFAT. JFK was supported by an Australian Research Council Discovery Project grant (DP150101172).

\section{SUPPLEMENTARY MATERIAL}

The Supplementary Material for this article can be found online at: https://www.frontiersin.org/articles/10.3389/fnsys. 2017.00074/full\#supplementary-material 


\section{REFERENCES}

Abril, S., Oliveras, J., and Gómez, C. (2007). Foraging activity and dietary spectrum of the Argentine ant (Hymenoptera: Formicidae) in invaded natural areas of the northeast Iberian Peninsula. Environ. Entomol. 36, 1166-1173. doi: 10.1603/0046-225x(2007)36[1166:faadso]2.0.co;2

Alekseyenko, O. V., Chan, Y. B., Fernandez, M. L., Bülow, T., Pankratz, M. J., and Kravitz, E. A. (2014). Single serotonergic neurons that modulate aggression in Drosophila. Curr. Biol. 24, 2700-2707. doi: 10.1016/j.cub.2014.09.051

Alekseyenko, O. V., Lee, C., and Kravitz, E. A. (2010). Targeted manipulation of serotonergic neurotransmission affects the escalation of aggression in adult male Drosophila melanogaster. PLoS One 5:e10806. doi: 10.1371/journal.pone. 0010806

Anstey, M. L., Rogers, S. M., Ott, S. R., Burrows, M., and Simpson, S. J. (2009). Serotonin mediates behavioral gregarization underlying swarm formation in desert locusts. Science 323, 627-630. doi: 10.1126/science.1165939

Aso, Y., Siwanowicz, I., Bräcker, L., Ito, K., Kitamoto, T., and Tanimoto, H. (2010). Specific dopaminergic neurons for the formation of labile aversive memory. Curr. Biol. 20, 1445-1451. doi: 10.1016/j.cub.2010.06.048

Baldwin, M. W., Toda, Y., Nakagita, T., O’Connell, M. J., Klasing, K. C., Misaka, T., et al. (2014). Evolution of sweet taste perception in hummingbirds by transformation of the ancestral umami receptor. Science 345, 929-933. doi: 10.1126/science.1255097

Barron, A. B., Maleszka, R., Vander Meer, R. K., and Robinson, G. E. (2007). Octopamine modulates honey bee dance behavior. Proc. Natl. Acad. Sci. U S A 104, 1703-1707. doi: 10.1073/pnas.0610506104

Barron, A. B., Søvik, E., and Cornish, J. L. (2010). The roles of dopamine and related compounds in reward-seeking behavior across animal phyla. Front. Behav. Neurosci. 4:163. doi: 10.3389/fnbeh.2010.00163

Bauknecht, P., and Jékely, G. (2017). Ancient coexistence of norepinephrine, tyramine and octopamine signaling in bilaterians. BMC Biol. 15:6. doi: 10.1186/s12915-016-0341-7

Beggs, K. T., Glendining, K. A., Marechal, N. M., Vergoz, V., Nakamura, I., Slesoor, K. N., et al. (2007). Queen pheromone modulates brain dopamine function in worker honey bees. Proc. Natl. Acad. Sci. U S A 104, 2460-2464. doi: 10.1073/pnas.0608224104

Bergan, J. F. (2015). Neural computation and neuromodulation underlying social behavior. Integr. Comp. Biol. 55, 268-280. doi: 10.1093/icb/icv061

Blenau, W., Erber, J., and Baumann, A. (1998). Characterization of a dopamine D1 receptor from Apis mellifera: cloning, functional expression, pharmacology, and mRNA localization in the brain. J. Neurochem. 70, 15-23. doi: 10.1046/j. 1471-4159.1998.70010015.x

Blenau, W., and Thamm, M. (2011). Distribution of serotonin (5-HT) and its receptors in the insect brain with focus on the mushroom bodies. Lessons from Drosophila melanogaster and Apis mellifera. Arthropod Struct. Dev. 40, 381-394. doi: 10.1016/j.asd.2011.01.004

Boulay, R., Hooper-Bui, L. M., and Woodring, J. (2001). Oviposition and oogenesis in virgin fire ant females Solenopsis invicta are associated with a high level of dopamine in the brain. Physiol. Entomol. 26, 294-299. doi: 10.1046/j.0307-6962. 2001.00250.x

Bourguignon, T., Lo, N., Cameron, S. L., Šobotník, J., Hayashi, Y., Shigenobu, S., et al. (2015). The evolutionary history of termites as inferred from 66 mitochondrial genomes. Mol. Biol. Evol. 32, 406-421. doi: 10.1093/molbev/msu308

Braun, G., and Bicker, G. (1992). Habituation of an appetitive reflex in the honeybee. J. Neurophysiol. 67, 588-598.

Brent, C. S., Miyasaki, K., Vuong, C., Miranda, B., Steele, B., Brent, K. G., et al. (2016). Regulatory roles of biogenic amines and juvenile hormone in the reproductive behavior of the western tarnished plant bug (Lygus hesperus). J. Comp. Physiol. B 186, 169-179. doi: 10.1007/s00360-015-0953-1

Bubak, A. N., Renner, K. J., and Swallow, J. G. (2014). Heightened serotonin influences contest outcome and enhances expression of high-intensity aggressive behaviors. Behav. Brain Res. 259, 137-142. doi: 10.1016/j.bbr.2013. 10.050

Buczkowski, G., Kumar, R., Suib, S. L., and Silverman, J. (2005). Dietrelated modification of cuticular hydrocarbon profiles of the Argentine ant, Linepithema humile, diminishes intercolony aggression. J. Chem. Ecol. 31, 829-843. doi: 10.1007/s10886-005-3547-7
Cardoen, D., Wenseleers, T., Ernst, U. R., Danneels, E. L., Laget, D., DE Graaf, D. C., et al. (2011). Genome-wide analysis of alternative reproductive phenotypes in honeybee workers. Mol. Ecol. 20, 4070-4084. doi: 10.1111/j. 1365-294X.2011.05254.x

Chvalova, D., Zdechovanova, L., Vaneckova, H., and Hodkova, M. (2014). Brain norepinephrine identified by mass spectrometry is associated with reproductive status of females of the linden bug Pyrrhocoris apterus. Comp. Biochem. Phys. B Biochem. Mol. Biol. 168, 70-75. doi: 10.1016/j.cbpb.2013.11.003

Claridge-Chang, A., Roorda, R. D., Vrontou, E., Sjulson, L., Li, H., Hirsh, J., et al (2009). Writing memories with light-addressable reinforcement circuitry. Cell 139, 405-415. doi: 10.1016/j.cell.2009.08.034

Costa, J. T. (2006). The Other Insect Societies. Cambridge, MA: Harvard University Press.

Couzin, I. D. (2009). Collective cognition in animal groups. Trends Cogn. Sci. 13, 36-43. doi: 10.1016/j.tics.2008.10.002

Crockett, M. J., Clark, L., and Robbins, T. W. (2009). Reconciling the role of serotonin in behavioral inhibition and aversion: acute tryptophan depletion abolishes punishment-induced inhibition in humans. J. Neurosci. 29, 11993-11999. doi: 10.1523/JNEUROSCI.2513-09.2009

Cunningham, C. B., Ji, L., Wiberg, R. A., Shelton, J., McKinney, E. C., Parker, D. J., et al. (2015). The genome and methylome of a beetle with complex social behavior, Nicrophorus vespilloides (Coleoptera: Silphidae). Genome Biol. Evol. 7, 3383-3396. doi: 10.1093/gbe/evv194

Cuvillier-Hot, V., and Lenoir, A. (2006). Biogenic amine levels, reproduction and social dominance in the queenless ant Streblognathus peetersi. Naturwissenschaften 93, 149-153. doi: 10.1007/s00114-006-0086-1

Czaczkes, T. J., Grüter, C., and Ratnieks, F. L. W. (2015). Trail pheromones: an integrative view of their role in social insect colony organization. Annu. Rev. Entomol. 60, 581-599. doi: 10.1146/annurev-ento-010814-020627

Dacks, A. M., Nickel, T., and Mitchell, B. K. (2003). An examination of serotonin and feeding in the flesh fly Neobellieria bullata (Sarcophagidae: Diptera) J. Insect Behav. 16, 1-21. doi: 10.1023/A:1022817610378

Dunbar, R. I. M. (1998). The social brain hypothesis. Evol. Anthropol. 6, 178-190 doi: 10.1002/(sici)1520-6505(1998)6:5<178::aid-evan5>3.3.co;2-p

Dussutour, A., and Simpson, S. J. (2008). Carbohydrate regulation in relation to colony growth in ants. J. Exp. Biol. 211, 2224-2232. doi: 10.1242/jeb. 017509

Dussutour, A., and Simpson, S. J. (2009). Communal nutrition in ants. Curr. Biol. 19, 740-744. doi: 10.1016/j.cub.2009.03.015

Eickwort, G. C. (1981). "Presocial insects," in Social Insects, ed. H. R. Hermann, (New York, NY: Academic Press), 199-281.

Falibene, A., Rössler, W., and Josens, R. (2012). Serotonin depresses feeding behaviour in ants. J. Insect Physiol. 58, 7-17. doi: 10.1016/j.jinsphys.2011. 08.015

Farina, W. M., and Grüter, C. (2009). "Trophallaxis: a mechanism of information transfer," in Contemp Top Entomol, eds S. Jarau and M. Hrncir (New York, NY: CRC Press), 173-187.

Feinerman, O., and Korman, A. (2017). Individual versus collective cognition in social insects. J. Exp. Biol. 220, 73-82. doi: 10.1242/jeb.143891

Fernstrom, J. D. (2013). Large neutral amino acids: dietary effects on brain neurochemistry and function. Amino Acids 45, 419-430. doi: 10.1007/s00726 012-1330-y

Field, J., Cronin, A., and Bridge, C. (2006). Future fitness and helping in social queues. Nature 441, 214-217. doi: 10.1038/nature04560

Field, J., Shreeves, G., Kennedy, M., Brace, S., and Gilbert, J. D. J. (2015). Sex-biased parental care and sexual size dimorphism in a provisioning arthropod. Behav. Ecol. Sociobiol. 69, 1897-1906. doi: 10.1007/s00265-015-2002-1

Fletcher, D. J., and Blum, M. S. (1981). Pheromonal control of dealation and oogenesis in virgin queen fire ants. Science 212, 73-75. doi: 10.1126/science. 212.4490.73

French, A. S., Simcock, K. L., Rolke, D., Gartside, S. E., Blenau, W., and Wright, G. A. (2014). The role of serotonin in feeding and gut contractions in the honeybee. J. Insect Physiol. 61, 8-15. doi: 10.1016/j.jinsphys.2013.12.005

Friedman, D. A., and Gordon, D. M. (2016). Ant genetics: reproductive physiology, worker morphology, and behavior. Ann. Rev. Neurosci. 39, 41-56. doi: 10.1146/annurev-neuro-070815-013927

Galbraith, D. A., Wang, Y., Amdam, G. V., Page, R. E., and Grozinger, C. M. (2015). Reproductive physiology mediates honey bee (Apis mellifera) 
worker responses to social cues. Behav. Ecol. Sociobiol. 69, 1511-1518. doi: 10.1007/s00265-015-1963-4

Gallo, V. P., Accordi, F., Chimenti, C., Civinini, A., and Crivellato, E. (2016). "Catecholaminergic system of invertebrates: comparative and evolutionary aspects in comparison with the octopaminergic system," in International Review of Cell and Molecular Biology, ed. K. W. Jeon (London: Elsevier Inc.), 363-394.

Giraldo, Y. M., Kamhi, J. F., Fourcassié, V., Moreau, M., Robson, S. K., Rusakov, A., et al. (2016). Lifespan behavioural and neural resilience in a social insect. Proc. Biol. Sci. 283:20152603. doi: 10.1098/rspb. 2015.2603

Giraldo, Y. M., Patel, E., Gronenberg, W., and Traniello, J. F. A. (2013). Division of labor and structural plasticity in an extrinsic serotonergic mushroom body neuron in the ant Pheidole dentata. Neurosci. Lett. 534, 107-111. doi: 10.1016/j. neulet.2012.11.057

Gotzek, D., and Ross, K. G. (2007). Genetic regulation of colony social organization in fire ants: an integrative overview. Q. Rev. Biol. 82, 201-226. doi: $10.1086 / 519965$

Greene, M. J., and Gordon, D. M. (2003). Social insects: cuticular hydrocarbons inform task decisions. Nature 423:32. doi: 10.1038/423032a

Greene, M. J., Pinter-Wollman, N., and Gordon, D. M. (2013). Interactions with combined chemical cues inform harvester ant foragers' decisions to leave the nest in search of food. PLoS One 8:e52219. doi: 10.1371/journal.pone. 0052219

Gronenberg, W., Ash, L. E., and Tibbetts, E. A. (2008). Correlation between facial pattern recognition and brain composition in paper wasps. Brain Behav. Evol. 71, 1-14. doi: 10.1159/000108607

Grozinger, C. M., Sharabash, N. M., Whitfield, C. W., and Robinson, G. E. (2003). Pheromone-mediated gene expression in the honey bee brain. Proc. Natl. Acad. Sci. U S A 100, 14519-14525. doi: 10.1073/pnas.2335884100

Hamilton, A. R., Shpigler, H., Bloch, G., Wheeler, D. E., and Robinson, G. E. (2017). "Endocrine influences on insect societies," in Hormones, Brain and Behavior, eds D. W. Pfaff and M. Joëls (Oxford: Academic Press), 421-452.

Hammer, M., and Menzel, R. (1998). Multiple sites of associative odor learning as revealed by local brain microinjections of octopamine in honeybees. Learn. Mem. 5, 146-156.

Harris, J. W., and Woodring, J. (1995). Elevated brain dopamine levels associated with ovary development in queenless worker honey bees (Apis mellifera L.). Comp. Biochem. Physiol. 3, 271-279. doi: 10.1016/0742-8413(95)00048-s

Haselton, A. T., Downer, K. E., Zylstra, J., and Stoffolano, J. G. (2009). Serotonin inhibits protein feeding in the blow fly, Phormia regina (Meigen). J. Insect Behav. 22, 452-463. doi: 10.1007/s10905-009-9184-1

Hauser, F., Cazzamali, G., Williamson, M., Blenau, W., and Grimmelikhuijzen, C. J. P. (2006). A review of neurohormone GPCRs present in the fruitfly Drosophila melanogaster and the honey bee Apis mellifera. Prog. Neurobiol. 80, 1-19. doi: 10.1016/j.pneurobio.2006. 07.005

Hirashima, A., Suetsugu, E., Hirokado, S., Kuwano, E., Taniguchi, E., and Eto, M. (1999). Effect of octopamine on the activity of juvenile-hormone esterase in the silkworm Bombyx mori and the red flour beetle Tribolium freemani. Gen. Comp. Endocrinol. 116, 373-381. doi: 10.1006/gcen.1999. 7378

Hoover, K. M., Bubak, A. N., Law, I. J., Yaeger, J. D. W., Renner, K. J., Swallow, J. G., et al. (2016). The organization of societal conflicts by pavement ants Tetramorium caespitum: an agent-based model of amine-mediated decision making. Curr. Zool. 62, 277-284. doi: 10.1093/cz/zow041

Hoover, S. E., Keeling, C. I., Winston, M. L., and Slessor, K. N. (2003). The effect of queen pheromones on worker honey bee ovary development. Naturwissenschaften 90, 477-480. doi: 10.1007/s00114-003-0462-Z

Hoyer, S. C., Eckart, A., Herrel, A., Zars, T., Fischer, S. A., Hardie, S. L., et al. (2008). Octopamine in male aggression of Drosophila. Curr. Biol. 18, 159-167. doi: 10.1016/j.cub.2007.12.052

Hoyle, G. (1985). "Generation of motor activity and control of behaviour: the role of the neuromodulator octopamine and the orchestration hypothesis," in Comparative Insect Physiology, Biochemistry and Pharmacology, eds G. A. Kerkut and L. Gilbert (Toronto: Pergamon Press), 607-621.

Ilies, I., Muscedere, M. L., and Traniello, J. F. (2015). Neuroanatomical and morphological trait clusters in the ant genus Pheidole: evidence for modularity and integration in brain structure. Brain Behav. Evol. 85, 63-76. doi: $10.1159 / 000370100$

Jeanson, R., Dussutour, A., and Fourcassie, V. (2012). Key factors for the emergence of collective decision in invertebrates. Front. Neurosci. 6:121. doi: 10.3389/fnins.2012.00121

Kamhi, J. F., Nunn, K., Robson, S. K. A., and Traniello, J. F. A. (2015). Polymorphism and division of labour in a socially complex ant: neuromodulation of aggression in the Australian weaver ant, Oecophylla smaragdina. Proc. Biol. Sci. 282:20150704. doi: 10.1098/rspb.2015.0704

Kamhi, J. F., and Traniello, J. F. A. (2013). Biogenic amines and collective organization in a superorganism: neuromodulation of social behavior in ants. Brain Behav. Evol. 82, 220-236. doi: 10.1159/000356091

Kay, A. D., Bruning, A. J., van Alst, A., Abrahamson, T. T., Hughes, W. O., and Kaspari, M. (2014). A carbohydrate-rich diet increases social immunity in ants. Proc. Biol. Sci. 281:20132374. doi: 10.1098/rspb.2013.2374

Kay, A. D., Shik, J. Z., Van Alst, A., Miller, K. A., and Kaspari, M. (2012). Diet composition does not affect ant colony tempo. Funct. Ecol. 26, 317-323. doi: 10.1111/j.1365-2435.2011.01944.x

Kay, A. D., Zumbusch, T., Heinen, J. L., Marsh, T. C., and Holway, D. A. (2010). Nutrition and interference competition have interactive effects on the behavior and performance of Argentine ants. Ecology 91, 57-64. doi: 10.1890/09 $-0908.1$

Kent, D. S., and Simpson, J. A. (1992). Eusociality in the beetle Austroplatypus incompertus (Coleoptera: Curculionidae). Naturwissenschaften 79, 86-87. doi: $10.1007 /$ bf01131810

Klemm, N., Hustert, R., Cantera, R., and Nässel, D. R. (1986). Neurons reactive to antibodies against serotonin in the stomatogastric nervous system and in the alimentary canal of locust and crickets (Orthoptera, Insecta). Neuroscience 17, 247-261. doi: 10.1016/0306-4522(86)90240-x

Kravitz, E. A., and Huber, R. (2003). Aggression in invertebrates. Curr. Opin. Neurobiol. 13, 736-743. doi: 10.1016/j.conb.2003.10.003

Lebestky, T., Chang, J. S., Dankert, H., Zelnik, L., Kim, Y. C., Han, K. A., et al. (2009). Two different forms of arousal in Drosophila are oppositely regulated by the dopamine D1 receptor ortholog DopR via distinct neural circuits. Neuron 64, 522-536. doi: 10.1016/j.neuron.2009.09.031

LeBoeuf, A. C., Benton, R., and Keller, L. (2013). The molecular basis of social behavior: models, methods and advances. Curr. Opin. Neurobiol. 23, 3-10. doi: 10.1016/j.conb.2012.08.008

LeBoeuf, A. C., Waridel, P., Brent, C. S., Goncalves, A. N., Menin, L., Ortiz, D., et al. (2016). Oral transfer of chemical cues, growth proteins and hormones in social insects. Elife 5:e20375. doi: 10.7554/eLife.20375

Liang, D., and Silverman, J. (2000). "You are what you eat": diet modifies cuticular hydrocarbons and nestmate recognition in the Argentine ant, Linepithema humile. Naturwissenschaften 87, 412-416. doi: 10.1007/s001140050752

Libbrecht, R., Oxley, P. R., Keller, L., and Kronauer, D. J. (2016). Robust DNA methylation in the clonal raider ant brain. Curr. Biol. 26, 391-395. doi: 10.1016/j.cub.2015.12.040

Libersat, F., and Pflueger, H. J. (2004). Monoamines and the orchestration of behavior. Biosci. 54, 17-25. doi: 10.1641/0006-3568(2004)054[0017:matoob]2. $0 . \operatorname{co} ; 2$

Lihoreau, M., Buhl, J., Charleston, M. A., Sword, G. A., Raubenheimer, D., and Simpson, S. J. (2015). Nutritional ecology beyond the individual: a conceptual framework for integrating nutrition and social interactions. Ecol. Lett. 18, 273-286. doi: 10.1111/ele.12406

Lihoreau, M., Latty, T., and Chittka, L. (2012). An exploration of the social brain hypothesis in insects. Front. Physiol. 3:442. doi: 10.3389/fphys.2012.00442

Liscia, A., Solari, P., Gibbons, S. T., Gelperin, A., and Stoffolano, J. G. Jr. (2012). Effect of serotonin and calcium on the supercontractile muscles of the adult blowfly crop. J. Insect Physiol. 58, 356-366. doi: 10.1016/j.jinsphys.2011.12.010

Lucas, C., and Sokolowski, M. B. (2009). Molecular basis for changes in behavioral state in ant social behaviors. Proc. Natl. Acad. Sci. U S A 106, 6351-6356. doi: $10.1073 /$ pnas.0809463106

Mercer, A. R., and Menzel, R. (1982). The effects of biogenic amines on conditioned and unconditioned responses to olfactory stimuli in the honeybee Apis mellifera. J. Comp. Physiol. 145, 363-368. doi: 10.1007/bf00619340

Misof, B., Liu, S. L., Meusemann, K., Peters, R. S., Donath, A., Mayer, C., et al. (2014). Phylogenomics resolves the timing and pattern of insect evolution. Science 346, 763-767. doi: 10.1126/science. 1257570 
Molaei, G., and Lange, A. B. (2003). The association of serotonin with the alimentary canal of the African migratory locust, Locusta migratoria: distribution, physiology and pharmacological profile. J. Insect. Physiol. 49, 1073-1082. doi: 10.1016/j.jinsphys.2003.08.004

Monastirioti, M. (1999). Biogenic amine systems in the fruit fly Drosophila melanogaster. Microsc. Res. Tech. 45, 106-121. doi: 10.1002/(sici)10970029(19990415)45:2<106::aid-jemt5 > 3.3.co;2-v

Moreau, C. S., and Bell, C. D. (2013). Testing the museum versus cradle tropical biological diversity hypothesis: phylogeny, diversification, and ancestral biogeographic range evolution of the ants. Evolution 67, 2240-2257. doi: $10.1111 /$ evo. 12105

Muscedere, M. L., Johnson, N., Gillis, B. C., Kamhi, J. F., and Traniello, J. F. A. (2012). Serotonin modulates worker responsiveness to trail pheromone in the ant Pheidole dentata. J. Comp. Physiol. A Neuroethol. Sens. Neural Behav. Physiol. 198, 219-227. doi: 10.1007/s00359-011-0701-2

Mustard, J. A., Beggs, K. T., and Mercer, A. R. (2005). Molecular biology of the invertebrate dopamine receptors. Arch. Insect Biochem. Physiol. 59, 103-117. doi: 10.1002/arch.20065

Nässel, D. R., and Laxmyr, L. (1983). Quantitative determination of biogenic amines and DOPA in the CNS of adult and larval blowflies, Calliphora erythrocephala. Comp. Biochem. Physiol. C 75, 259-265. doi: 10.1016/07428413(83)90190-1

Neckameyer, W. S. (1998). Dopamine modulates female sexual receptivity in Drosophila melanogaster. J. Neurogenet. 12, 101-114. doi: 10.3109/01677069809167259

Neckameyer, W. S. (2010). A trophic role for serotonin in the development of a simple feeding circuit. Dev. Neurosci. 32, 217-237. doi: 10.1159/000304888

O'Connell, L. A., and Hofmann, H. A. (2011a). Genes, hormones, and circuits: an integrative approach to study the evolution of social behavior. Front. Neuroendocrinol. 32, 320-335. doi: 10.1016/j.yfrne.2010.12.004

O'Connell, L. A., and Hofmann, H. A. (2011b). The vertebrate mesolimbic reward system and social behavior network: a comparative synthesis. J. Comp. Neurol. 519, 3599-3639. doi: 10.1002/cne.22735

O'Connell, L. A., and Hofmann, H. A. (2012). Evolution of a vertebrate social decision-making network. Science 336, 1154-1157. doi: 10.1126/science. 1218889

Okada, Y., Sasaki, K., Miyazaki, S., Shimoji, H., Tsuji, K., and Miura, T. (2015). Social dominance and reproductive differentiation mediated by dopaminergic signaling in a queenless ant. J. Exp. Biol. 218, 1091-1098. doi: 10.1242/jeb. 118414

Oster, G. F., and Wilson, E. O. (1978). Caste and Ecology in the Social Insects. Princeton, NJ: Princeton University Press.

Ott, S. R., and Rogers, S. M. (2010). Gregarious desert locusts have substantially larger brains with altered proportions compared with the solitarious phase. Proc. Biol. Sci. 277, 3087-3096. doi: 10.1098/rspb.2010.0694

Panaitof, S. C., Yaeger, J. D. W., Speer, J. P., and Renner, K. J. (2016). Biparental behavior in the burying beetle Nicrophorus orbicollis: a role for dopamine? Curr. Zool. 62, 285-291. doi: 10.1093/cz/zow032

Pastor, D., Piulachs, M. D., Cassier, P., André, M., and Bellés, X. (1991). In vivo and in vitro study of the action of dopamine on oocyte growth and juvenile hormone production in Blattella germanica (L.) (Dictyoptera; Blattellidae). C. R. Acad. Sci. III 313, 207-212.

Penick, C. A., Brent, C. S., Dolezal, K., and Liebig, J. (2014). Neurohormonal changes associated with ritualized combat and the formation of a reproductive hierarchy in the ant Harpegnathos saltator. J. Exp. Biol. 217, 1496-1503. doi: $10.1242 /$ jeb.098301

Perry, C. J., Baciadonna, L., and Chittka, L. (2016). Unexpected rewards induce dopamine-dependent positive emotion-like state changes in bumblebees. Science 353, 1529-1531. doi: 10.1126/science.aaf4454

Regier, J. C., Mitter, C., Zwick, A., Bazinet, A. L., Cummings, M. P., Kawahara, A. Y., et al. (2013). A large-scale, higher-level, molecular phylogenetic study of the insect order Lepidoptera (moths and butterflies). PLoS One 8:e58568. doi: 10.1371/journal.pone. 0058568

Reid, C. R., Lutz, M. J., Powell, S., Kao, A. B., Couzine, I. D., and Garnier, S. (2015). Army ants dynamically adjust living bridges in response to a cost-benefit trade-off. Proc. Natl. Acad. Sci. U S A 112, 15113-15118. doi: 10.1073/pnas. 1512241112
Robinson, G. E., Heuser, L. M., Le Conte, Y., Lenquette, F., and Hollingworth, R. M. (1999). Neurochemicals aid bee nestmate recognition. Nature 399, 534-535. doi: 10.1038/21095

Roeder, T. (1999). Octopamine in invertebrates. Prog. Neurobiol. 59, 533-561. doi: 10.1016/S0301-0082(99)00016-7

Sasaki, T., and Pratt, S. C. (2012). Groups have a larger cognitive capacity than individuals. Curr. Biol. 22, R827-R829. doi: 10.1016/j.cub.2012.07.058

Sasaki, K., Yamasaki, K., and Nagao, T. (2007). Neuro-endocrine correlates of ovarian development and egg-laying behaviors in the primitively eusocial wasp (Polistes chinensis). J. Insect Physiol. 53, 940-949. doi: 10.1016/j.jinsphys.2007. 03.006

Schmidt, C. (2013). Molecular phylogenetics of ponerine ants (Hymenoptera: Formicidae: Ponerinae). Zootaxa 3647, 201-250. doi: 10.11646/zootaxa. 3647.2.1

Schulz, D. J., Barron, A. B., and Robinson, G. E. (2002). A role for octopamine in honey bee division of labor. Brain Behav. Evol. 60, 350-359. doi: 10.1159/000067788

Schwaerzel, M., Monastirioti, M., Scholz, H., Friggi-Grelin, F., Birman, S., and Heisenberg, M. (2003). Dopamine and octopamine differentiate between aversive and appetitive olfactory memories in Drosophila. J. Neurosci. 23, 10495-10502.

Seeley, T. D. (1989). Social foraging in honey bees: how nectar foragers assess their colony's nutritional status. Behav. Ecol. Sociobiol. 24, 181-199. doi: 10.1007/bf00292101

Seeley, T. D. (2010). Honeybee Democracy. Princeton, NJ: Princeton University Press.

Seid, M. A., Goode, K., Li, C., and Traniello, J. F. A. (2008). Age- and subcasterelated patterns of serotonergic immunoreactivity in the optic lobes of the ant Pheidole dentata. Dev. Neurobiol. 68, 1325-1333. doi: 10.1002/dneu.20663

Seid, M. A., and Traniello, J. F. A. (2005). Age-related changes in biogenic amines in individual brains of the ant Pheidole dentata. Naturwissenschaften 92, 198-201. doi: 10.1007/s00114-005-0610-8

Sheehan, M. J., and Tibbetts, E. A. (2011). Specialized face learning is associated with individual recognition in paper wasps. Science 334, 1272-1275. doi: 10.1126/science.1211334

Shimoji, H., Aonuma, H., Miura, T., Tsuji, K., Sasaki, K., and Okada, Y. (2017). Queen contact and among-worker interactions dually suppress worker brain dopamine as a potential regulator of reproduction in an ant. Behav. Ecol. Sociobiol. 71:35. doi: 10.1007/s00265-016-2263-3

Simola, D. F., Graham, R. J., Brady, C. M., Enzmann, B. L., Desplan, C., Ray, A., et al. (2016). Epigenetic (re)programming of caste-specific behavior in the ant Camponotus floridanus. Science 351:aac6633. doi: 10.1126/science.aac6633

Simpson, S. J., and Raubenheimer, D. (2012). The Nature of Nutrition: A Unifying Framework from Animal Adaptation to Human Obesity. Princeton, NJ: Princeton University Press.

Simpson, S. J., and Stevenson, P. A. (2015). "Neuromodulation of social behavior in insects," in The Oxford Handbook of Molecular Psychology, ed. T. Canli (New York, NY: Oxford University Press), 27-51.

Sinakevitch, I., Mustard, J. A., and Smith, B. H. (2011). Distribution of the octopamine receptor AmOA1 in the honey bee brain. PLoS One 6:e14536. doi: 10.1371/journal.pone.0014536

Sobotka, J. A., Daley, M., Chandrasekaran, S., Rubin, B. D., and Thompson, G. J. (2016). Structure and function of gene regulatory networks associated with worker sterility in honeybees. Ecol. Evol. 6, 1692-1701. doi: 10.1002/ece3.1997

Sombati, S., and Hoyle, G. (1984). Generation of specific behaviors in a locust by local release into neuropil of the natural neuromodulator octopamine. J. Neurobiol. 15, 481-506. doi: 10.1002/neu.480150607

Song, H. J., Amédégnato, C., Cigliano, M. M., Desutter-Grandcolas, L., Heads, S. W., Huang, Y., et al. (2015). 300 million years of diversification: elucidating the patterns of orthopteran evolution based on comprehensive taxon and gene sampling. Cladistics 31, 621-651. doi: 10.1111/cla.12116

Song, N., Liang, A. P., and Bu, C. P. (2012). A molecular phylogeny of Hemiptera inferred from mitochondrial genome sequences. PLoS One 7:e48778. doi: 10.1371/journal.pone.0048778

Stevenson, P. A., Hofmann, H. A., Schoch, K., and Schildberger, K. (2000). The fight and flight responses of crickets depleted of biogenic amines. J. Neurobiol. 43, 107-120. doi: 10.1002/(sici)1097-4695(200005)43:2<107::aid-neu1>3.3. co; $2-3$ 
Stevenson, P. A., and Rillich, J. (2017). Neuromodulators and the control of aggression in crickets. in The Cricket as a Model Organism: Development, Regeneration, and Behavior, eds H. Wilson Horch, T. Mito, A. Popadic, H. Ohuchi and S. Noji (Tokyo, Japan: Springer), 169-195.

Stoffolano, J. G., Acaron, A., and Conway, M. (2008). "Bubbling” or droplet regurgitation in both sexes of adult Phormia regina (Diptera: Calliphoridae) fed various concentrations of sugar and protein solutions. Ann. Entomol. Soc. Am. 101, 964-970. doi: 10.1603/0013-8746(2008)101[964:bodrib]2. $0 . \operatorname{co} ; 2$

Stroeymeyt, N., Guerrieri, F. J., van Zweden, J. S., and d'Ettorre, P. (2010). Rapid decision-making with side-specific perceptual discrimination in ants. PLoS One 5:e12377. doi: 10.1371/journal.pone.0012377

Sturgis, S. J., and Gordon, D. M. (2012). Nestmate recognition in ants (Hymenoptera: Formicidae): a review. Myrm. News 16, 101-110.

Thompson, F. J., Donaldson, L., Johnstone, R. A., Field, J., and Cant, M. A. (2014). Dominant aggression as a deterrent signal in paper wasps. Behav. Ecol. 25, 706-715. doi: 10.1093/beheco/aru063

Thompson, G. J., Hurd, P. L., and Crespi, B. J. (2013). Genes underlying altruism. Biol. Lett. 9:20130395. doi: 10.1098/rsbl.2013.0395

Thompson, G. J., Yockey, H., Lim, J., and Oldroyd, B. P. (2007). Experimental manipulation of ovary activation and gene expression in honey bee (Apis mellifera) queens and workers: testing hypotheses of reproductive regulation. J. Exp. Zool. A Ecol. Genet. Physiol. 307, 600-610. doi: 10.1002/jez.415

Thorne, B. L., and Traniello, J. F. (2003). Comparative social biology of basal taxa of ants and termites. Annu. Rev. Entomol. 48, 283-306. doi: 10.1146/annurev. ento.48.091801.112611

Tibbetts, E. A. (2013). The function, development, and evolutionary stability of conventional signals of fighting ability. Adv. Study Behav. 45, 49-80. doi: 10.1016/b978-0-12-407186-5.00002-1

Traniello, J. F. A. (1977). Recruitment behavior, orientation, and the organization of foraging in the carpenter ant Camponotus pennsylvanicus degeer (Hymenoptera: Formicidae). Behav. Ecol. Sociobiol. 2, 61-79. doi: $10.1007 / \mathrm{bf00299289}$

Trible, W., and Kronauer, D. J. (2017). Caste development and evolution in ants: it's all about size. J. Exp. Biol. 220, 53-62. doi: 10.1242/jeb.145292

Vander Meer, R. K., Preston, C. A., and Hefetz, A. (2008). Queen regulates biogenic amine level and nestmate recognition in workers of the fire ant, Solenopsis invicta. Naturwissenschaften 95, 1155-1158. doi: 10.1007/s00114008-0432-6

Vargas, M. A., Luo, N., Yamaguchi, A., and Kapahi, P. (2010). A role for S6 kinase and serotonin in postmating dietary switch and balance of nutrients in $D$. melanogaster. Curr. Biol. 20, 1006-1011. doi: 10.1016/j.cub.2010.04.009
Wada-Katsumata, A., Yamaoka, R., and Aonuma, H. (2011). Social interactions influence dopamine and octopamine homeostasis in the brain of the ant Formica Japonica. J. Exp. Biol. 214, 1707-1713. doi: 10.1242/jeb. 051565

Wang, Y., Li, H., Wang, P., Song, F., and Cai, W. Z. (2014). Comparative mitogenomics of plant bugs (Hemiptera: Miridae): identifying the AGG codon reassignments between serine and lysine. PLoS One 9:e101375. doi: 10.1371/journal.pone.0101375

Wiegmann, B. M., Trautwein, M. D., Winkler, I. S., Barr, N. B., Kim, J. W., Lambkin, C., et al. (2011). Episodic radiations in the fly tree of life. Proc. Natl. Acad. Sci. U S A 108, 5690-5695. doi: 10.1073/pnas. 1012675108

Wilson, E. O. (1971). The Insect Societies. Cambridge, MA: Belknap Press of Harvard University.

Wnuk, A., Wiater, M., and Godzinska, E. J. (2010). Effect of past and present behavioural specialization on brain levels of biogenic amines in workers of the red wood ant Formica polyctena. Physiol. Entomol. 36, 54-61. doi: 10.1111/j. 1365-3032.2010.00762.x

Yuan, Q., Joiner, W. J., and Sehgal, A. (2006). A sleep-promoting role for the Drosophila serotonin receptor 1A. Curr. Biol. 16, 1051-1062. doi: 10.1016/j.cub. 2006.04.032

Yuan, Q., Lin, F., Zheng, X., and Sehgal, A. (2005). Serotonin modulates circadian entrainment in Drosophila. Neuron 47, 115-127. doi: 10.1016/j.neuron.2005. 05.027

Zhou, C., Rao, Y., and Rao, Y. (2008). A subset of octopaminergic neurons are important for Drosophila aggression. Nat. Neurosci. 11, 1059-1067. doi: $10.1038 / \mathrm{nn} .2164$

Conflict of Interest Statement: The authors declare that the research was conducted in the absence of any commercial or financial relationships that could be construed as a potential conflict of interest.

The reviewer VM declared a past collaboration with one of the authors CSM to the handling Editor.

Copyright (c) 2017 Kamhi, Arganda, Moreau and Traniello. This is an open-access article distributed under the terms of the Creative Commons Attribution License (CC BY). The use, distribution or reproduction in other forums is permitted, provided the original author(s) or licensor are credited and that the original publication in this journal is cited, in accordance with accepted academic practice. No use, distribution or reproduction is permitted which does not comply with these terms. 